\title{
Denture Tagging: An Overview of Simple And Complex Methods
}

Mohammad Arif Lone ${ }^{1}$, Ramanpreet Ranauta², Syed Mohammad Noorani ${ }^{3}$, Manu Rana ${ }^{4}$, Nuzhat Ara ${ }^{5}$

\section{Quick Response Code}

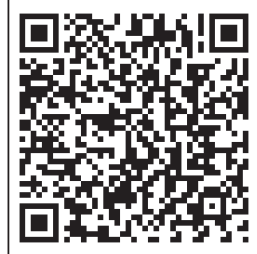

\section{doi: $10.5866 / 2015.7 .10147$}

${ }^{1}$ Registrar

Department of Dentistry Sher-i-Kashmir Institute of Medical Sciences Bemina Srinagar J ammu \& Kashmir 2Post Graduate Student

Department Of Prosthodontics Swami Devi Dyal Hospital and Dental College Barwala Panchkula, Haryana

${ }^{3}$ Registrar

Department of Prosthodontics Mansarovar Dental College, Bhopal, M.P

${ }^{4}$ Registrar

Department of Endodontics M.B.Kedia Dental College, Birgunj, Nepal

${ }^{5}$ P.G student

Oral Medicine and Radiology J aipur Dental College, J aipur, Rajasthan

\section{Article Info:}

Received: April 13, 2015

Review Completed: May 13, 2015

Accepted: J une 10, 2015

Available Online: April, 2015 (www.nacd.in)

(C) NAD, 2015 - All rights reserved

\section{Email for correspondence:}

mohammadpgprostho@gmail.com

\begin{abstract}
:
Dentures are used to restore the functions of the oral cavity and naming or tagging make it very easy to identify the denture, maintain record and create a more personal and ambient atmosphere for the patient and the technician to whom the prosthetic work is relegated. Denture tagging can be helpful in identification of human bodies with prosthesis during natural disasters and calamities. After Second World War nearly 3000 unidentified soldiers were identified by denture prosthesis.

Identification is important in medico legal cases, disposal of diseased property dispute cases, insurance policies or claim for compensation. A denture labeling method should maintain all the basic requirements of American Dental Association, but till date no methods fulfills all the requirements. This review articles will come up with all the methods that can be done for labeling, their benefits and limitations.
\end{abstract}

Key words: Denture Tagging Methods, Forensic odontology, Denture Identification

\section{INTRODUCTION}

Humans live in a civilised society and have the right of recognition which makes identification and communication easy within the system. Every person is unique and has some typical feature through which recognition becomes easy like fair or dark skin, scars, tattoos, long hair, blue eyes, moles or facial deformities etc. The methods of identifying persons in Indian subcontinent are by I card, Passport, Adhar card, Electric Bill, Pan Card, Voter 
Card, Birth Certificate, Death Certificate but when the identity is at threat from natural calamities like fire, trauma, road traffic accident, floods like Tsunami, hurricane like (Katrina, Hud-Hud) fall from height, landslides, aviation disaster, cataclysmic holocausts or unconscious person, medico-legal, Health issues likeAlzheimer's disease, war crimes etc, identity of human body can be a challenging task.

In the present world every individual has the right to recognition "article 6 of united nations declaration of human rights". ${ }^{1}$ Forensic odontology is of tremendous help in settling those cases with lost identity like it helped in mass disaster cases like Tsunami in Thailand. In some serious disaster cases denture can be the only source of identification. $^{2}$

The American Dental Associations has prescribed some basic requirements for denture labeling, that the strength of the material must not be jeopardised, should be easy to achieve, should be efficient and durable, markings should be visible, should be inert and inexpensive, and possible to retrieve, withstand temperature, humidity and disinfection. ${ }^{3}$ Dental tagging can be donein the form of patients name, age, sex, address, job profile, state address, phone number. The various methods of Tagging are as under. ${ }^{4,5}$

\section{1) SURFACE METHOD $6-8$}

In surface method the marks are located on one of the denture's surface and can be made by "scribing or engraving" the denture. "Embossing" comprises of initials of the name that are scratched with a bur on the master cast (Figure 1). This technique produces embossed lettering on the surface of the denture (Figure 2). Denture labelling can be done by blade of laboratory knife exposing only the tip, Cut the patients name or social security number on the buccal surface of Distolingual flange, Rub with no. 2 lead pencil or ink pen over fine grooves.

In surface technique, letters or numbers are engraved with a small round dental bur on the fitting surface of the complete denture (Figure 3). Alternate method is to dry the tissue surface of the denture and writethe name with a number 2 pencil. This method requires frequent remarking possibly every 3-4 weeks. Denture can be engraved with Electropen introduced by Wecker with an invisible ink that gets illuminated by UV radiations.

Both these surface methods are very simpleand cost effective but the main limitation of this methods is that it can lead to roughening of the denture surface, food entrapment, bacterial colonisation \& tissue irritation. 9 , 10

\section{2) MEMORY CARD ${ }^{11}$}

Memory Card is a data storage device used for storing files like audio, video clips, pictures, voice messages or text documents. The data of the card can be read with the help of card reader in any computer. Thememory card can be embedded in the acrylic and can be easily retrieved from it without distortion (Figure 4). It does not interfere with the oral function or strength of the material and no special training is needed for the procedure.

The cost of the memory card is also very economical. The limitations with the card are that in case of extensive impact the card may get damaged. During thermal tests, memory card can withstand temperature between -25 to $85^{\circ} \mathrm{C}$ and cannot be durable in fire or aviation disasters when temperature may rise up to $600^{\circ} \mathrm{C}^{12}$

\section{3) STAINLESS STEEL TAPE METHOD ${ }^{13}$}

Denture labelling can be done with the help of a stainless steel tape of the dimensions $9.5 \times 125 \mathrm{~mm}$ this is an easy methods of labelling denture and can be done by a small round bur that can engrave the patient's name, identification number (for example, social security number). The limitation with this method is that markings are not readily visible and it is difficult to write on a thin metal strip with a bur. Steel tape will also not compliment the denture instead it acts as a contrast to the denture base and will lead to an unesthetic appearance.

\section{4) ABSORBENT TISSUE PAPER ${ }^{14}$}

Denture tagging can be done by typing the patients information (Figure 5) on the tissue paper and during trial closure the tissue paper can be 


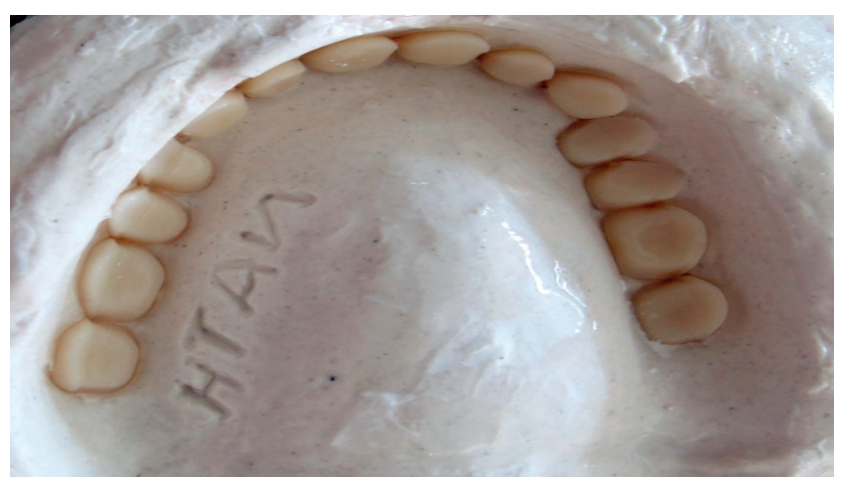

Figure 1: Surface Inscribed on Mold

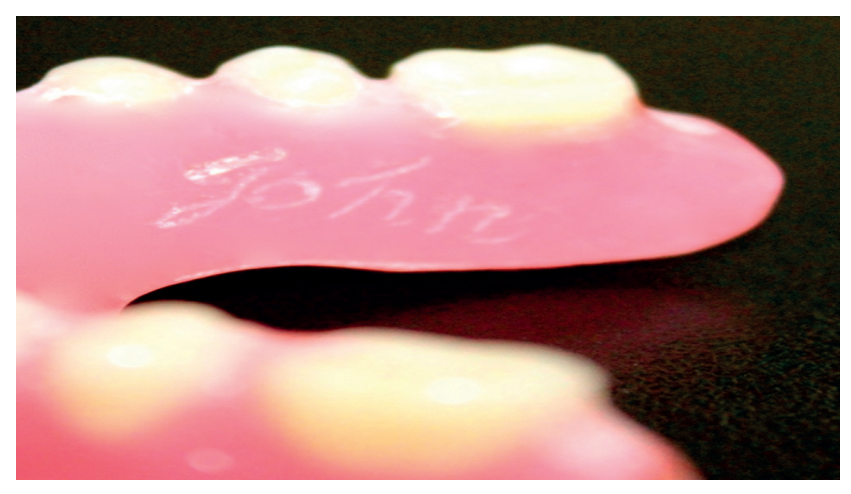

Figure 3: Scribing by Bur

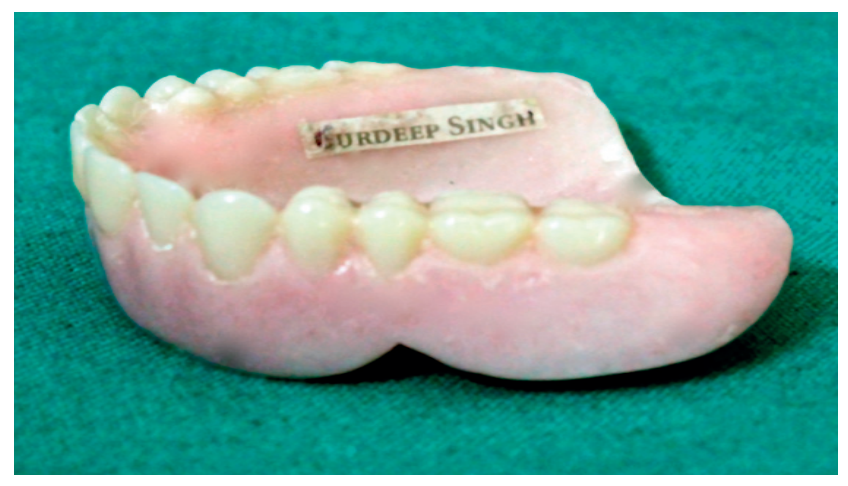

Figure 5: Labelling by Tissue Paper

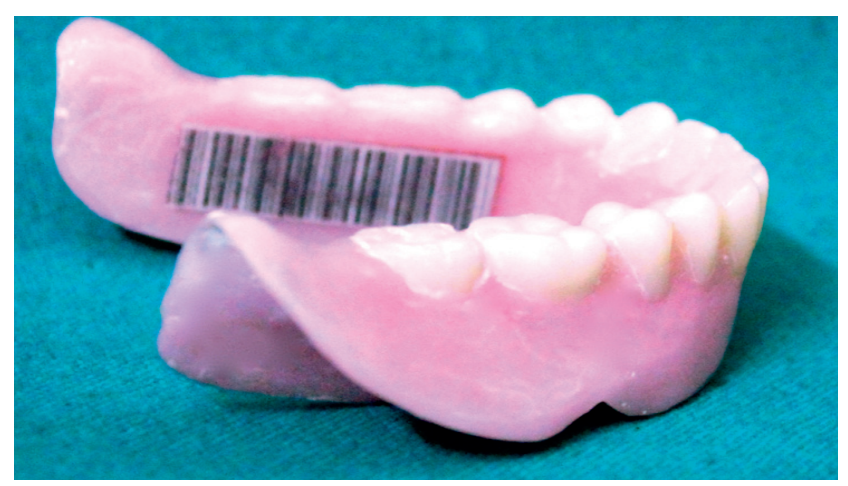

Figure 7: Denture Labelling by Bar-Coding

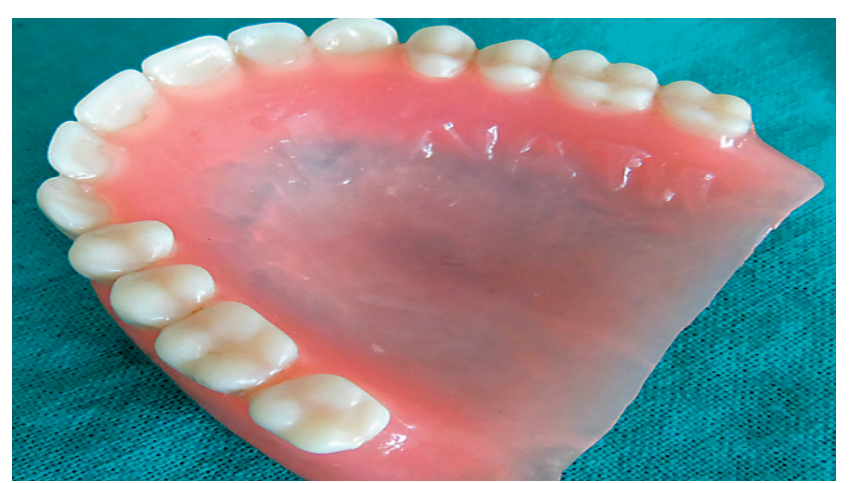

Figure 2: Surface Method on Denture

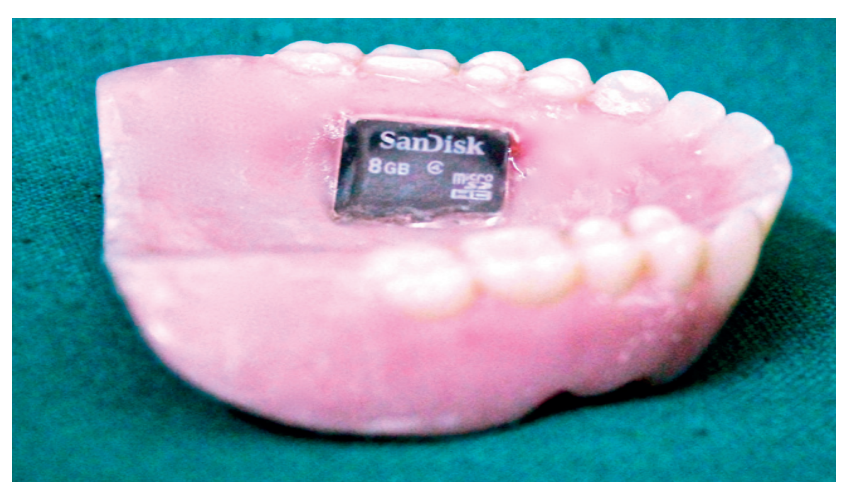

Figure 4: Memory Card in Denture

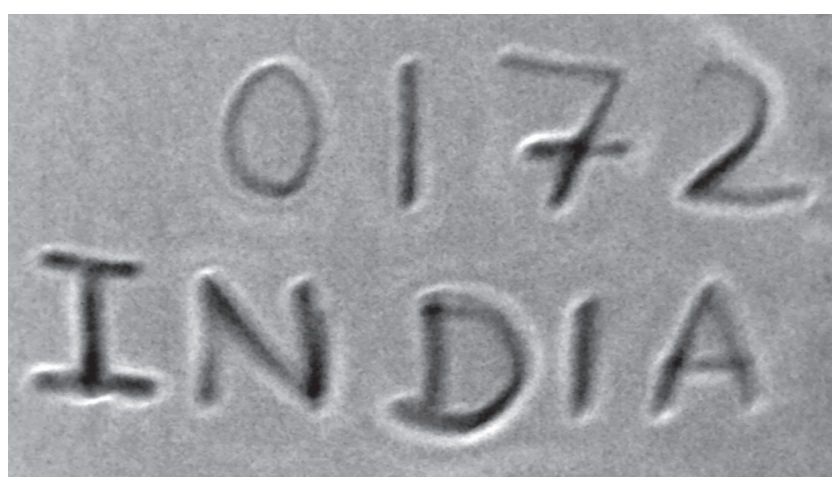

Figure 6: Radiographic Method

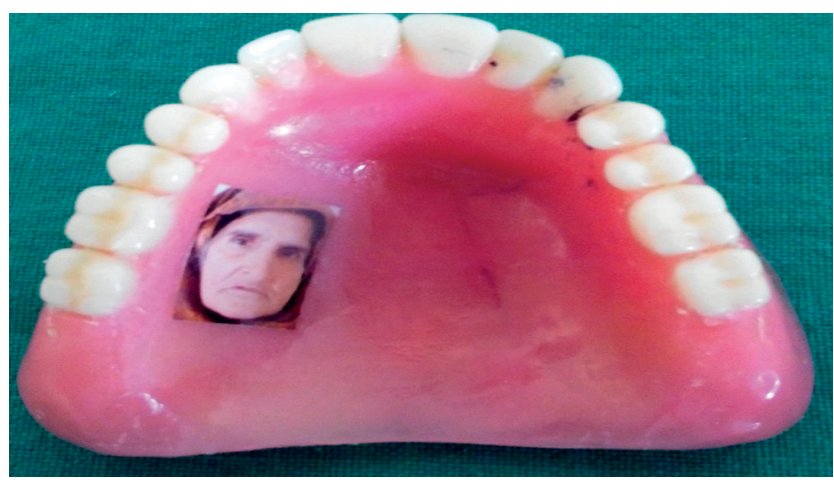

Figure 8: Labelling By Photo 
placed within the resin dough but thelimitation with this method is that information is very limited and it is not fire or chemical resistant.

The absorption of lot of monomer may weaken the tissue paper and lead to dispersion of the ink used for writing on the paper, so it cannot maintain the information over a prolonged period of time.

\section{5) RADIOGRAPHIC FILMS ${ }^{15}$}

In this method the lead foil is incorporated within the denture after dewaxing the denture as required. Place a Layer of acrylic in the mold space and within this resin, place the lead foil $(2.5 \times 6 \mathrm{~mm})$ on which all the details that are to be incorporated are written with a $0.5 \mathrm{~mm}$ ball point pen tip. The lead foil should contain all the details that are to be incorporated within the denture. After denture processing the patient's denture can be identified by taking an IOPAR (Figure 6) of the processed denture to see the details.

Moreover this method has proved to be simple, easy, quick, durable and cosmetically acceptable, fulfilling all requirements of A.D.A

\section{6) DENTURE BAR-CODING ${ }^{12,16}$}

This machine readable technique involves printing a number code on paper, photographing the paper and making a negative of the photo. After this the negative image is transferred to the piece of silk. The silk is fixed over the rim of the device worn to pattern ceramic faience, and a plain piece of white faience is placed underneath the rim. Then faience paint containing black ceramic is applied to the negative barcode region on the silk, and a device forces the paint all the way through thesilk, creating an image on the white faience. Finally the faience is heated at 860 for 30 minutes, after which we ensure that the barcode can be read.

The main advantage with this system is that a lot of information can be stored within the bar code and it is fire resistant up to $600^{\circ} \mathrm{C}$. But to read the information within the barcode (Figure 7) a scanner and a computer is needed and during placement of the bar code it may get distorted dueto the curvature of the palate.

\section{7) PHOTOGRAPHS ${ }^{17}$}

One of the easiest methods of denture tagging is by using patients photograph (Figure 8 ). It is easy to recognise, this methods can be beneficial for uneducated people also who cannot be familiar with other methods of denture labelling. Patient feels more attached with the denture as it distinguished itself from the rest of complete or removable prosthesis. However thermal tests have revealed that the photographic marker were only resistant to temperature around $200-300^{\circ} \mathrm{C}$.

\section{8) LENTICULAR CARD ${ }^{18}$}

Lenticular card is a newer method of denture tagging in which a lens is used with an illusion of depth, morph or the ability to change as viewed from different angles e.g. it is like Rupees 500 Indian currency notes that changes col or from green to blue when viewed under different directions. Lenticular card is a polyethylene tetra phthalate card having patient's details that is processed by the manufacturer and the same can be put in the denture after processing and can be covered with clear acrylic. The Lenticular card showed no signs of deterioration of fading for months together.

\section{9) LASER ETCHING ${ }^{19}$}

Copper vapour laser (CVL) can etch patient's identification into the non impression surface of the metal partial denture. It can label the cobaltchromium components of dentures easily, legibly and reduce the font size of the data. The CVL beam is focused and delivered to the material surface by the two-axis scanner mounted with mirrors. Computer is used to controls the movement of the scanner and the firing of the CVL. The limitation with this method is that it is expensive and also requires specialized equipment and technician's to perform the procedure and this method cannot be used to etch on acrylic resin.

\section{CONCLUSION}

Though denture labelling is discussed and appreciated in every forum of dentistry but still the concept is not introduced at the basic level. The reasons behind not labelling dentures could be from 
three factors i.e. Dentists who don't pay attention to such procedures, Patients who are not educated enough to understand the importance of labelling and the laboratory personals who are not interested in doing so. Denture labelling should al so match the standards of labelling as set by American Dental Association. Though there are many methods of denture labelling but none fill all the requirements of American Dental Association.

Dentists should raise awareness and motivate the patients about the benefits and uses of denture labelling. The reassurance and education on behalf of the dentist can help the patent in understanding the fact that labelling will add features to the denture. Also during processing of the denture in the laboratory the lab personal should be well trained and should take due care to maintain the strength and esthetics of the denture.

\section{References:}

1. Harvey W. Identity by teeth and marking of denture. $\mathrm{Br}$ Dent J 1996; 121:334-340

2. Berry FA, Logan GI, Plata R, Riegel R. A post fabrication technique for identification of prosthetic devices. J Prosthet Dent 1995; 73(4):341-343.

3. Clark DH, Cainio P. Practical forensic dentistry. Butterworth -Heinemann, Boston 1992.

4. Wolfardt CP. Denture identification system. J Prosthet Dent 1995; 74:551-554.

5. MatsmuraH, Shimoe S. (2002) Incorporation of a cast, embossed identification plate into a partial denture framework. J Prosthet Dent 2002; 88:215-216.

6. Stimson PG, Meltz CA. Forensic dentistry .CRC Press, Boco Raton. 1997.
7. Shepherd M. Automatic identification of dental appliances. Br Dent J 1997; 182:171-174.

8. Takahashi F, Koji T, Morita O. Durable method of denture identification. J Prosthet Dent 1998; 28.

9. Stevenson RB. Marking dentures for identification. J Prosthet Dent 1987; 58:255-256.

10. Heath J R, Zoitopoulos L, Griffiths C. Simple method for denture identification: a simple approach. J Oral Rehabil 1987; 14:147-163.

11. Luthra R, Arora S, Meshram S. Denture marking for forensic identification using memory card: An innovative technique. J Indian Prosthodontic Soc 2012; 12(4): 231-235.

12. Anglo S, Zortuk M, Beydemir K. Denture Bar-coding. New horiz Br Dent J 2009; 206:589-590

13. Padmanabhan TV, Gupta RK. Denture marking: an introduction and review. J Forensic Dent Sci 2009; 1(1): 11-16

14. Thomas CJ : The role of the denture in identification: A review. J Forensic Odontostomatol 1984; 2:13-16

15. Mohan J, Kumar CD, Simon P: Denture Marking as an aid to forensic identification. J Indian Prosthodont Soc 2012; 12(3):131-136.

16. Rajendran V, Karthigeyan S, Manoharam S. Denture marker using a two dimensional bar code. J Prosthet Dent 2012; 107:207-208

17. Anehosar GV, Acharya AB, Nadiger RK. Usefulness of patient photograph as a marker for identifying denture wearers in India. Gerodontology 2010; 27:272-277.

18. Colvenkar SS. Lenticular Card: A new method for denture identification Indian J Dental Res 2010; 21:112-114

19. Ling BC, Nambiar P, Low KS, Lee CK. Copper vapour laser ID Labelling on metal dentures and restorations. J Forensic Odontostomatol. 2003; 21:17-22.

\section{Gain quick access to our journal online View our journal at www.nacd.in}

